\title{
EPISTEMOLOGI TAFSIR SUFI AL-GHAZALI DAN PERGESERANNYA
}

\author{
Wahyudi \\ Institut Agama Islam Ma'arif (IAIM) NU Metro Lampung \\ e-mail: wahyudiragil447@gmail.com
}

\begin{abstract}
In the history of tafsir development, there is a certain moment where there are some interactions between the Qur'an and the Sufis. Epistemologically, Sufis have a peculiar characteristic in looking at the Qur'an. The Sufis thaught that the Qur'an has two dimensions, esoteric and exoteric. These two sides are one unity and can not be separated. Al-Ghazali has its own nomenclature to refer to the zahir and inner sides of the Qur'an. The esoteric and exoteric dimensions of the Qur'an in the term al-Ghazali are called 'ilm sadf and 'ilm lubāb. The process of crossing from sadf to lubāb involves the role of imagination in istiqāmah suluk ilā Allāh. Viewed from the perspective of epidemiological division ala Abid al-Jabiri, the epistemology of al-Ghazali include the category of 'irfänī. But in its development al-Ghazali made a dialectic between the epistemology 'irfānī and bayānī at the same time, although the nuances of irfäni still remain dominant. This research attempts to answer the problem of how the process of the dialectic epistemology of al-Ghazali and how its building style. This kind of dialectic is one of al-Ghazali effort to built the harmonization between sadf science which tends to bayānī with the science of lubāb which tend to irfänī. Clearly, the process of this dialectic can be seen in one of his works Ihyō' 'Ulüm al-Dīn. This research uses the qualitative method and includes library research.
\end{abstract}

\begin{abstract}
Abstrak: Dalam sejarah perkembangan tafsir, ada momen tertentu saat terjadi interaksi antara al-Qur'an dan kaum Sufi. Secara epistemologis, para Sufi memiliki ciri khas dalam memandang al-Qur'an. Kaum Sufi memandang bahwa Qur'an memiliki dua dimensi, esoterik dan eksoteris. Dua dimensi ini merupakan satu kesatuan dan tidak dapat dipisahkan. Al-Ghazali memiliki nomenklatur tersendiri untuk menyebut sisi zahir dan bațin al-Qur'an. Dimensi esoterik dan eksoterik al-Qur'an dalam istilah al-Ghazali disebut dengan 'ilm sadf dan 'ilm lubab. Proses penyebrangan dari sadf ke lubāb ini melibatkan peran khayal dengan cara istiqāmah suluk ilā Allah. Ditinjau dari perspektif pembagian epistemologi ala Abid al-Jabiri, epistemologi al-Ghazali masuk dalam kategori 'irfānī. Namun dalam perkembangannya al-Ghazali melakukan dialektika antara epistemologi 'irfānī dan bayānī secara bersamaan, meskipun nuansa 'irfānī masih tetap dominan. Penelitian ini berupaya untuk menjawab rumusan masalah bagaimana proses dialektika epistemologi al-Ghazali dan bagaimana corak bangunannya. Dialektika ini merupakan upaya harmonisasi al-Ghazali antara ilmu sadf yang cenderung bayānī dengan ilmu lubab yang mendekati 'irfānī. Secara jelas proses dialektika ini dapat dilihat dalam salah satu karyanya Ihyo' Ulūm al-Dīn. Penelitian ini menggunakan metode kualitatif dan merupakan penelitian kepustakaan.
\end{abstract}

Keywords: epistemology; tafseer; sufi 


\section{A. Pendahuluan}

Abu Hamid al-Ghazālī atau Imam al-Ghazālī menyebutkan dalam kitab Jawāhir al-Qur'an, jika seseorang hendak mengetahui ilmu awal dan akhir maka pelajarilah al-Qur'an. Senada dengan al-Ghazali, Darraz menyatakan bahwa alQur'an seperti permata yang memancarkan sinar berbeda dalam tiap sisinya. Artinya, al-Qur'an merupakan kitab suci yang multi-interpretasi. ${ }^{1}$ Dalam realitasnya, ketika al-Qur'an bersinggungan dengan tradisi sufisme, para ulama berbeda pendapat mengenai keabsahan epsitemologi sufi dalam menjelaskan ayat-ayat al-Qur'an. Sebagian ulama berpendapat, bahwa ta'wil atau penjelasan sufi terhadap ayat-ayat al-Qur'an tidak dapat diterima sebagai tafsir, pendapat ini di antaranya diungkapkan oleh Ibn al-Ṣalāh dan al-Zarkashi. ${ }^{2}$

Sementara ulama lain, seperti al-Ṭabātabāii dapat menerima dengan syarat; penjelasan tersebut tidak menafikan makna yang terkandung dalam pengertian tekstual (eksoterik) ayat al-Qur'an. Penafsiran tersebut diperkuat dalil syara' lain. Makna esoterik yang dijelaskan oleh para sufi tidak bertentangan dengan makna eksoteriknya dan tidak mengacaukan pemahaman orang awam. ${ }^{3}$

Sedang Quraish Shihab berpendapat bahwa tafsir ishari dapat diterima selama: maknanya lurus, tidak bertentangan dengan hakikat-hakikat keagamaan, tidak juga dengan lafal ayat, tidak menyatakan bahwa itulah satusatunya makna untuk ayat yang ditafsirkan, terdapat korelasi antara makna ishāri yang ditarik oleh sufi dari tesk al-Qur'an dengan zahir ayat al-Qur'an, ada dukungan dari sumber ajaran agama yang mendukung makna ishāri tersebut. ${ }^{4}$

Secara umum jika ditinjau dari perspektif teori al-'aql al-'arabi (nalar Arab) yang disusun oleh Muhammad 'Ābid al-Jābirī, maka tafsir sufi masuk dalam epistemologi 'irfānī. Namun dalam perkembanganya, tiga epistemologi, bayānī, burhānī dan 'irfānī saling tarik menarik. Meskipun secara garis besar tafsir sufi masuk dalam epistemologi 'irfänī, pada tataran praktisnya terdapat persinggungan antara epistemologi 'irfānī dengan dua epistemologi lainnya.

1Wahyudi, "Ta'wīl Sufi al-Ghazali dan Ibn 'Arabī terhadap Ayat-ayat al-Qur'an (Studi Komparatif)" (UIN Sunan Ampel Surabaya, 2017), 1.

²Badr al-Dīn al-Zarkashi, al-Burhān fi 'Ulūm al-Qur'ān, vol. II (Beirut: Dār al-Kutūb al-'Ilmiyah, 2012), 105.

3al-Ṭabāțabāi, al-Mizān, vol. V (Beirut: Ismailiyan, Dar al-Kutub al-Islamiyah, t.th.), 281.

${ }^{4}$ M. Quraish Shihab, Kaidah Tafsir (Tangerang: Lentara Hati, 2013), 370. 
Hal ini terbukti dengan munculnya Suhrawardi yang mencoba mensintesikan antara epistemologi burhānī dan 'irfānī. Hasil sintesis yang dilakukan oleh Suhrawardi memunculkan istilah Hikmah al-Ishrāqiyyah yang kemudian dikenal dengan mazhab tasawuf falsafinya. Sebagaimana Suhrawardi, Muhāsibi juga mencoba mengharmonisasikan secara elektif antara nalar bayānī dan 'irfānī yang kemudian dikenal dengan mazhab tasawuf Sunni.

Upaya harmonisasi yang dilakukan oleh kedua ulama ini tidak melepaskan nalar 'irfānī sebagai basic utama epistemologi kaum sufi. Pengetahuan 'irfānī tidak diperoleh berdasarkan analisa teks tetapi dengan olah ruhani dan dengan kesucian hati. Dengan modal olah ruhani dan pembersihan hati ini diharapkan Tuhan akan melimpahkan pengetahuan secara langsung kepadanya. Epistemologi 'irfānī secara umum menggunakan kashf dan ilhām sebagai metode memperoleh pengetahuan serta bertujuan menyatu dengan Tuhan. ${ }^{5}$ Setidaknya pengetahuan dalam perspektif epistemologi irfänī dapat diperoleh melalui tiga tahapan. Yakni persiapan, penerimaan dan pengungkapan dengan lisan atau tulisan (takhalli, taḥalli dan tajalli).

Di kalangan tokoh tafsir sufi, al-Ghazali merupakan nama yang familiar. alGhazali berupaya merumuskan metodologi penakwilan 'irfānī melalui buku Jawāhir al-Qur'an. Dalam buku tersebut al-Ghazali berupaya menjelaskan langkah-langkah metodologis dalam menakwilkan al-Qur'an agar tidak berhenti dalam tataran zahir teks semata. Ia berasumsi bahwa ada makna yang lebih dalam di balik makna teks tersebut. Secara umum al-Ghazali masuk dalam kategori ulama yang mengembangkan epistemologi 'irfānī. Namun sebagaimana Suhrawardi dan Muhasibi, meskipun tidak secara ekplisit, al-Ghazali juga melakukan harmonisasi terhadap berbagai macam epistemologi. Hipotesis ini didasarkan pada sejarah hidup al-Ghazali yang bergelut dalam berbagai macam bidang ilmu dan pada akhirnya memilih jalan sufi yang cenderung 'irfānī.

Dengan metode kualitatif yang merupakan kajian kepustakaan, penelitian ini mengkaji epistemologi yang dikembangkan oleh al-Ghazali, serta pergeserannya dalam perspektif epistemologi ala Abid al-Jabiri.

${ }^{5}$ Muhammad 'Abid al-Jābirī, Bunyah al-'Aql al-'Araby (Bairut: Markaz Dirāsāt al-Waḥdah al'Arabiyyah, 2009), 251. 


\section{B. Biografi al-Ghazali}

Imam al-Ghazali memiliki nama lengkap Abu Hamd Muhammad bin Muhammad al-Ghzali al-Tusi al-Syafi'i. Al-Ghazali lahir pada tahun 1058 M/450 H di kota Tus, ${ }^{6}$ sebuah distrik di Khurasan sebelah Timur Laut Persia. ${ }^{7}$ Abu Hamid al-Ghazali memiliki saudara yang konsen dalam bidang sufi Ahmad alGhazali (w. 520 H/1126 M di Qazwin. Iran). ${ }^{8}$ Al-Ghazali kehilangan ayahnya semenjak kecil, namun sebelum ayahnya meninggal, ia dititipkan kepada salah satu temannya yang menggeluti bidang tasawuf. Kepada teman ayahnya inilah al-Ghazali mendapat pendidikan pertamanya. Pada usia tujuh tahun al-Ghazali belajar bahasa Arab, Persia dan prinsip-prinsip agama. Menjelang umur lima belas tahun al-Ghazali pindah ke kota Jurjan, sekitar 160 kilometer dari kota Ṭu. Tahun berikutnya al-Ghazali kembali ke Țus, menghafal dan memahami apa yang telah ia peroleh dari para gurunya. ${ }^{9}$

Kemudian al-Ghazali melanjutkan pendidikannya ke Naisabur yang merupakan salah satu kota penting dalam perkembangan ilmu kepengetahuan di dunia Islam..$^{10}$ Di sana al-Ghazali bertemu dengan imam al-Juwayni atau yang terkenal dengan sebutan al-Harayman seorang teolog besar, pemimpin sekolah yang beraliran Ash'ariyah.11 Dalam kisaran usia dua puluh delapan tahun, alGhazali terlibat aktif dalam percaturan politik pemerintah. Dia menjadi salah satu hakim pengadilan bani Saljuk selama enam tahun. Ketika menjadi hakim alGhazali aktif menulis karya, salah satunya yang terpenting adalah al-Mustaziri dan al-I'tiqād fi al-I'qtisāā.12 Setelah lima tahun memegang jabatan itu yakni dari tahun 1090 M sampai tahun 1095 M ia mengundurkan diri. ${ }^{13}$

\footnotetext{
6Mohandas Gandhi, “Karamchand (1869-1948)," Global Encyclopaedia of Islamic Mystics and Mysticism 1 (2009): 91.

${ }^{7}$ Shaikh M Ghazanfar dkk, Economic thought of al-Ghazali (450-505 A.H./1058-1111 A.D.) (Jeddah, Saudi Arabia: Scientific Pub. Center, King Abdulaziz University, 2011), 5. 201.

${ }^{8}$ Henry Corbin, History of Islamic Philosophy (London: The Institute of Ismaili Studies, t.th.),

9Gandhi, “Karamchand (1869-1948)," 1.

${ }^{10}$ Henry Corbin, History of Islamic Philosophy, 180.

${ }^{11}$ Kamarudin Haji Salleh, "An Examination on the Nature of al-Ghazali Sufism," Islämiyyāt 17 (1996): 52.

${ }^{12}$ Gandhi, “Karamchand (1869-1948)," 2.

${ }^{13}$ Azyumardi Azra, "Al-Ghazāllī, Ensiklopedi Islam (Jakarta: Ichtiar Baru Van Hoeve, 2005), 204.
} 
Ketika itu kehidupanya goncang karena keraguan yang meliputinya, "apakah jalan yang ditempuhnya ini sudah benar atau tidak?" Perasaan shak ini timbul setalah mempelajari ilmu kalam (teologi) yang diperolehnya dari alJuwaini. Teologi membahas berbagai macam aliran yang satu sama lain terdapat kontradiksi. Al-Ghazali mulai tidak percaya dengan ilmu pengetahuan yang diperolehnya dari panca indra, sebab sering kali panca indra salah atau berdusta. Ia kemudian meletakkan kepercayaan kepada pengetahuan akal, akan tetapi ternyata juga tidak memuaskan. Tasawuflah yang kemudian menghilangkan rasa shak dalam dirinya. Pegetahuan tasawuf yang diperolehnya melalui qalb membuat al-Ghazali merasa yakin bahwa ia mendapatkan pengetahuan yang benar. ${ }^{14}$

Pada tahun 488 H al-Ghazali pergi menuju Hijaz, kemudian ke Damaskus dan Bait al-Maqdis selama beberapa waktu. Pada masa rihlah itulah ia menulis karya monumentalnya Ihyā' Ulüm al-Dīn, sebuah kitab yang memadukan antara fikih dan tasawuf. Pengaruh kitab ini menyelimuti seluruh dunia Islam dan masih terasa kuat sampai sekarang. Pada tahun $1105 \mathrm{M}$, al-Ghazali kembali kepada tugasnya semula, mengajar di madrasah Niẓamiyah, memenuhi panggilan Fakr al-Mulk putra Niz̧am al-Mulk, akan tetapi tugas ini tidak lama dijalankannya. Ia kembali ke țus, kota kelahirannya. Di sana ia mendirikan halaqah (sekolah khusus calon sufi) yang diasuhnya sampai ia wafat.15

Selama hidupnya al-Ghazali menulis banyak karya dalam berbagai macam bidang ilmu pengetahuan. Mulai dari logika, filsafat, teologi, moral dan al-Qur'an. Menurut penelitian yang dilakukan oleh Fayzullayeva karya al-Ghazali mencapai lebih dari seratus buku. ${ }^{16}$ Karya al-Ghazali banyak diterjemahkan ke dalam bahasa Inggris, Latin, Perancis, Jerman dan Indonesia. ${ }^{17}$ Karya-karyanya ditulis dalam bahasa Arab dan Persia diantarnya:

Dalam bidang ilmu ușūl fiqh dan fiqh antara lain, al-Muștafā min 'Ilm al-Ușūl, al-Basīt, al-Wasīt, al-Wajiz fi Fiqh al-Imām al-Shāfi'i, Asās al-Qiyās dan Khulāșāh al-Mukhtașar. Dalam bidang ilmu kalām dan filsafat antara lain, al-Tahāfut al-

${ }^{14} \mathrm{Azra}$, "Al-Ghazālī," 204.

${ }^{15} \mathrm{Azra}$, “Al-Ghazālī," 205.

16Fayzullayeva Ms, "Ethics of Communication in Philosophy Muhammad Al-Ghazali," Arts and Social Sciences Journal 09, no. 03 (2018): 1, https://doi.org/10.4172/2151-6200.1000345.

${ }^{17}$ Abdu Mujib, Biografi al-Ghazali Beserta Karya-Karyanya (t.tp: CV Bintang Remaja, t.th), 12. 
Falāsifah, al-Munqid min 'I-Ḍalāl, Fayșal al-Tafriqah bain al-Islām wa '-Zindiqah, al-Iqtișād fi al-'T'tiqād, Maqūṣid al-Falāsifah, al-Mustahdịīī, Mi'yār al-IIm, dan alQisțās al-Mustaqīm.18

Dalam bidang ilmu al-Qur'an antara lain, Qanūn fi al-Ta'wīl, Jawāhir alQur'ān dan Tafsìr Yaqūt al-Ta'wīl. Adapun dalam bidang akhlak dan tasawuf diantara karya al-Ghazali adalah, 'Ihyō' 'Ulūm al-Dīn, Mīzōn al-'Amal, Mishkāt alAnwār, Bidāyah al-Hidāyah, Kìmìyā'al-Sa'ādah, dan Talbiss Iblīs. ${ }^{19}$

\section{Pola Interaksi al-Qur'an dan Sufisme}

Dalam perspektif Ignaz Goldziher, tradisi sufi dalam Islam tidak bersumber murni dari ajaran Islam. Menurutnya, tradisi sufisme dalam Islam berlangsung secara gradual. Pertama gerakan ini muncul sebagai sikap zuhud secara total dan menjauhi kehidupan dunia. Selanjutnya terpengaruh pemikiran emanasi yang populer di kalangan neo-platonisme dan akhirnya sampai pada perasaan (emosi) yang naik ke atas dan berujung pada perasaan rindu kepada Allah. Ignaz juga beranggapan bahwa ajaran sufisme tidak bersumber dari al-Qur'an tetapi sumber rujukan dari sufisme adalah paham emanasi Neo-Platonisme. Munculnya tafsir-tafsir al-Qur'an yang bercorak sufi merupakan upaya para pelaku sufi untuk mencari legitimasi kebenaran atas paham sufi yang dianutnya. Meskipun menurut Ignaz proses pencarian pembenaran ini tidaklah mudah..$^{20}$

Berbeda dengan Ignaz yang menyatakan bahwa interaksi antara sufisme dan al-Qur'an berlangsung secara eisegesis (dari gagasan ke teks), Massignon seorang pengkaji Islam asal Perancis menyatakan bahwa sumber utama tafsir sufi adalah riyāḍah dan laku spiritual. Pengetahuan dalam perspektif sufi merupakan limpahan ilahiyah (al-fayḍ al-Ilahiyyah) yang bersifat transendental, diturunkan kepada jiwa manusia sesuai dengan tingkatan dan kesiapan jiwa mereka. ${ }^{21}$ Dalam hal ini para sufi membangun teori maqāmāt dan aḥwāl, yang menyatakan bahwa jiwa manusia memiliki maqām-maqām (check points) yang

${ }^{18} \mathrm{Abu}$ Hamid Muhammad bin Muhammad al-Ghazāli, Mishkāt al-Anwār (Beirut: 'Ālam alKutub, 1982), 23-25.

${ }^{19}$ Rahman Badawi, Muallafāt al-Ghazāli (Kuwait: Wakālah al-Maṭbūāt, 1977), 12-16.

${ }^{20}$ Ignaz Goldziher, Madhāhib al-Tafsìr al-Islāmy (Kairo: Maktabah al-Khānja, 1955), 201.

${ }^{21}$ Muhammad 'Abd al-Rāzaq Louis Massignon, al-Tașawwuf (Beirut: Dār al-Kitab al-Lubnani, 1984), 55. 
didaki satu persatu untuk mencapai ma'rifat.22 Dari uraian ini agaknya Masignon tidak setuju jika interaksi antara al-Qur'an dan sufisme berlangsung secara eisegesis (dari gagasan ke teks). Nampaknya ia lebih cenderung kepada pola interaksi exegesis (dari teks ke gagasan).

Husayn al-Dhahabi mengambil jalan tengah, dalam perspektifnya pola interaksi antara al-Qur'an dan sufisme berlangsung secara exegenis dan eisegesis sekaligus. Hal ini didasarkan pada pembagian tasawuf menjadi dua ragam, yakni tasawuf nazari (teoritis) dan tasawuf amali (praktis).23 Pendapat ini didukung oleh penjelasan Abū al-Wafā al-Taftazāni. ${ }^{24}$ Ia menyatakan bahwa secara umum ada dua kategori orientasi sufisme yang berkembang mulai abad ke-3 dan 4 Hijriyah. Dimana pada era ini terdapat bergeser paradigma sufisme, dari praktek asketis murni kepada wacana keilmuan yang terkodifikasi.

Orientasi pertama adalah aliran tasawuf moderat (mu'tadilūn) yang melandasi doktrinya dengan konfirmasi kepada teks atau ajaran al-Qur'an dan sunah. Aliran ini selanjutnya dikenal dengan tasawuf sunny karena para pengikut tasawuf ini berasal dari golongan ahl al-sunnah wa l-jamä'ah. Aliran sufi ini juga disebut dengan golongan tașawwuf akhläqī, karena didominasi dengan karakteristik moralitas. Salah satu perwakilan aliran ini adalah Junayd al-Baghdādī (w. 298 H). Selanjutnya orientasi ini terus berkembang di abad ke-5 $\mathrm{H}$ dengan al-Qushayry (w. $465 \mathrm{H}$ ) dan al-Ghazali (w. $505 \mathrm{H}$ ).

Orientasi tasawauf lainnya menurutnya adalah aliran semi-filosofis (shibh falsafy). Aliran ini terpesona dengan konsep fanā (annihilation) dan mengembangkan konsep terkait hubungan manusia dengan Tuhan seperti hulül. Tokoh utamanya adalah Abu Yazid al-Bustamy (w. 261 H) dan al-Hallaj (w. 301 H). Memasuki abad ke-5 dan ke-6 H, orientasi ini kemudian menjadi lebih filosofis dengan masuknya pengaruh ajaran neo-platonisme. Dalam hal ini, orientasi yang semi-filosofis menjadi seluruhnya filosofis, sehingga disebut dengan tasawuf falsafy. Aliran ini merupakan suatu aliran sufisme yang memadukan antara visi mistis dan visi rasional. Tasawuf ini menggunakan terminologi filosofis dalam

\footnotetext{
${ }^{22}$ Annemarie Schimmel, Mystical Dimensions of Islam (Chapel Hill: The University of North Carolina Press, 1975), 98.

${ }^{23}$ Husayn al-Dhahāby, al-Tafsīr wa al-Munfasirūn, vol. II (t.tp: Maktabah Muṣ'ab bin 'Amr alIslamiyah, 2004), 82.

${ }^{24} \mathrm{Abu}$ Wafa al-Taftazāni, al-Madkhal ilā al-Tașawwuf al-Islāmy (Kairo: Dār al-Thaqāfah li alNashr wa al-Tawzi', t.th), 99-143.
} 
pengungkapannya yang berasal dari berbagai macam ajaran filsafat. Suhrāwardi (w. $638 \mathrm{H}$ ) dengan teori ishrāqiyyah (illuminasi) dan Ibn 'Arabī (w. 638 H) dengan teori waḥdah al-wujūd (kesatuan eksistensi) merupakan perwakilan varian ini.

\section{Epistemologi Tafsir sufi al-Ghazali dan Pergeserannya}

Meskipun al-Ghazali bergelut dan menulis dalam berbagai bidang ilmu keislaman, namun pada akhirnya al-Ghazali menjadikan sufi sebagai jalan hidupnya. Sebagaimana umumnya, kaum sufi memiliki epistemologi yang khas. AlGhazali dan kaum sufi memiliki pandangan bahwa al-Qur'an mempunyai sisi zahir (eksoteris) dan sisi batin (esoteris). Dua sisi ini dalam perspektif al-Ghazali merupakan satu kesatuan dan tidak dapat dipisahkan. Mustahil seseorang dapat memahami sisi esoterik al-Qur'an tanpa melalui pemahaman sisi eksoterik terlebih dahulu.

Al-Ghazali menolak sikap sebagian kelompok yang hanya berpegang kepada kebenaran tunggal dalam tafsir al-Qur'an, seperti golongan zāhiriyah dan kelompok bäținiyah, ${ }^{25}$ maupun golongan yang hanya melihat kebenaran tafsir dengan model tafsir bi 'l-riwāyah yakni penafsiran yang hanya merujuk kepada hadis Nabi dan pendapat para sahabat. ${ }^{26}$ Penolakan al-Ghazali terhadap kelompok yang berdiri di atas absolutisme tafsir karena menurutnya akan mengarah pada sikap yang picik dan sempit dan pada gilirannya berdampak kepada pemahaman subjektif saat menafsirkan al-Qur'an. Produk penafsiran yang dihasilkan dari satu dimensi saja menurut al-Ghazali hanya bisa memberikan arti dan manfaat bagi dirinya sendiri dan nilai kebenarannya hanya untuk pribadinya, ${ }^{27}$ tidak untuk pihak lain. ${ }^{28}$

Di antara argumen al-Ghazali menolak penafsiran yang hanya menggunakan metode riwayat adalah sebagai berikut: Pertama, jika tafsir al-Qur'an harus

\footnotetext{
25al-Ghazāli menyebut kelompok zāhiriyah dengan istilah hasyawīy, sedang kelompok yang hanya berpengang teguh pada makna batin dengan sebutan bațini. lihat al-Ghazāli, Mishkāt al-Anwār, 160-61.

${ }^{26} \mathrm{Abu}$ Hamid Muhammad bin Muhammad al-Ghazāli, Ihyā' 'Ulūm al-Dīn (Beirut: Dār Ibn Hazm, 2005), 343.

${ }^{27}$ Penafsiran yang hanya memperhatikan satu sisi literal saja akan berdampak pada cara beragama yang sempit dan mudah menyalahkan orang lain. Lihat, Arif Chasbullah Chasbullah dan Wahyudi Wahyudi, "Deradikalisasi terhadap Penafsiran Ayat-ayat Qital," Fikri: Jurnal Kajian Agama, Sosial dan Budaya 2, No. 2 (Desember 2017): 410.

${ }^{28}$ al-Ghazāli, 'Ihyā' Ulüm al-Dīn, 343.
} 
selalu mengacu kepada hadis dan athar sahabat maka hal itu hanya bisa dilakukan dan diterapkan untuk sebagian ayat saja. Kedua, terjadi perbedaan pendapat di kalangan sahabat dalam menafsirkan al-Qur'an ini menunjukan bahwa sahabat juga mengfungsikan rasio dalam menafsirkan al-Qur'an. Bahkan perbedaan tersebut kadang tidak bisa dikompromikan. ${ }^{29}$ Ketiga, Nabi telah mendoakan Ibn 'Abbas agar menjadi orang yang ahli dalam bidang ta'wīl. Menurut al-Ghazali jika yang dimaksud dengan ta' will adalah riwayat maka tentu tidak ada artinya pemberian keistimewaan Nabi terhadap Ibn 'Abbas. ${ }^{30}$

Penolakan al-Ghazali atas absolutisme penafsiran didukung dengan keyakinan bahwa al-Qur'an memiki banyak dimensi untuk ditafsirkan dan dipahami. Sebagaimana hadis:

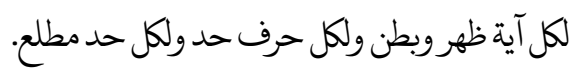

Setiap ayat memiliki zahir dan bațin, setiap huruf memiliki had dan setiap had memiliki mața'.

Hadis di atas merupakan hadis yang sangat populer dalam tradisi sufisme, Syi'ah dan kelompok Isma'iliyyah. Ia kemudian menjadi inspirasi bagi pergerakan kaum esoteris dalam tradisi pemikiran Islam, termasuk dalam konteks tafsir al-Qur'an. Beberapa kitab tafsir sufistik seperti Haqāíq al-Tafsïr, ${ }^{31}$ Rüh al$M a^{\prime} \bar{a} i^{32}$ dan Rüh al-Bayān ${ }^{33}$ secara langsung mengutip hadis tersebut sebagai landasan pengarangnya dalam menafsirkan suatu ayat. Dalam hal ini, Saḥl alTustari juga sering memakai redaksi "hādhā bātin al-'âyat" ketika mengidentifikasi makna esoteris suatu ayat. ${ }^{34}$

Ada beragam penjelasan di kalangan ulama mengenai zahir, bațin, had dan mațla'. Diantaranya dikutip oleh al-Zarqani dalam Manāhil al-Irfān bahwa zahir

${ }^{29}$ Menurut al-Ghazāli tidak semua penafsiran sahabat merupakan hasil rujukan pada sunnah Nabi sebab jelas, beberapa di antara memberi komentar masing-masing terhadap makna al-Qur'an. Contoh yang diberikan al-Ghazali adalah tentang al-ahrūf al-muqatța'ah.menurutnya penafsiran atau penakwilan tentang ayat ini setidaknya terdiri dari tujuh pendapat yang berbeda dan tidak mungkin bisa dikompromikan. Lihat, al-Ghazāli, Ihyō' 'Ulüm al-Dīn, 343.

${ }^{30}$ al-Ghazāli, Ihyā' 'Ulūm al-Dìn, 343. 2001), 21.

${ }^{31} \mathrm{Abū}$ Abd al-Raḥman al-Sulamī, Haqā’iq al-Tafsīr, vol. I (Beirut: Dār al-kutub al-'Ilmiyah,

${ }^{32}$ Maḥmud al-Alusī, Rūh al-Ma'āni, vol. I (Beirut: Dar Ihya' al-Turath al-'Araby, t.th.), 7.

33Ismāil Haqqy al-Istambūlī, Rūḥ al-Bayan, vol. I (Beirut: Dar Ihya' al-Turath al-'Araby, t.th.), 62.

${ }^{34}$ Saḥl al-Tustari, Tafsir al-Qur'an al-Ażìm (Kairo: Dār al-Hir lī al-Turath, t.th.), 131. 
adalah teks ayat, adapun bațin adalah ta'wïl-nya. Sementara had adalah setiap hukum yang berkisar tentang pahala dan siksa sedangkan mațla' adalah dimensi makrifat. 35

Haris al-Muhasibi (w. $243 \mathrm{H}$ ) memberi penjelasan bahwa yang dimaksud dengan makna zāhhir (literal meaning) adalah bacaan al-Qur'an (tilawah) dan yang dimaksud dengan makna bātịn (the hidden meaning) adalah pemahaman yang mendalam terhadap al-Qur'an ( $\left(a^{\prime}{ }^{\prime} w \bar{l}\right)$. Baik makna pada dataran literal meaning maupun the hidden meaning belum bisa sampai pada level hadd (the limit of intrepretation). Orang yang bisa mencapai atau menembus batas penafsiran sampai level had hanyalah al-Siddiqūn, yakni orang sufi yang pandai dan bersungguh-sungguh mampu untuk memasuki makna al-Qur'an secara mendalam. Mereka memahami seluruh ayat al-Qur'an dengan cara seperti pemahaman yang Allah berikan kepadanya. Beberapa kaum sufi mendasari satu peralihan ini dari penafsiran manusia kepada pemahaman Tuhan. Dalam pandangan sufi, langkah ini diambil ketika seseorang telah mencapai titik transedensi (mațla). ${ }^{36}$

Konsep tentang ketegorisasi makna al-Qur'an menjadi eksotersi (žāhir ${ }^{37}$ dan esoteris (bāțin) merupakan konsep yang mendasar dalam tafsir sufistik. Tradisi tafsir sufi, baik sufi nazari maupun isyari berawal dari pemahaman bahwa al-Qur'an memiliki beberapa level makna. Manusia memiliki potensi untuk menyingkap makna tersebut dan tugas penafsiran adalah tidak terbatas. ${ }^{38}$

Dalam tafsir sufi dualisme makna ayat al-Qur'an (esoteris dan eksoteris) adalah hal yang sangat penting. Dengan demikian sumber utama dari aktifitas penafsiran sufisme adalah intuisi (kasyf/isharat khafiyah) yang didapat melalui perilaku spiritual tertentu. Dalam sufisme ada suatu level dimana rasio tidak berfungsi secara normal sebagaimana sufi yang sedang mengalami jadhab (divine attraction) yang tidak akan bisa mengungkapkan pengalamannya dalam 80.

${ }^{35}$ Abd al-'Aẓim al-Zarqānī, Manāhil al-'Irfān fi 'Ulūm al-Qur'ān, vol. II (Beirut: Dār al-Fikr, 1988),

36Kurdi, dkk, Hermeneutika Al-Qur'an dan Hadis (Yogyakarta: el-Saq, 2010), 49.

37Dalam memahami al-Qur'an, kaum sufi tidak hanya berhenti dalam tataran zahir saja. Lihat Musharraf Maryam, "A Study on the Sufi Interpretation of Qur'ān and The Theory of Hermeneutic," Al-Bayan Journal 11, no. 1 (2013): 34, https://doi.org/10.11136/jqh.1311.01.03.

${ }^{38}$ Kristin Zahra Sands, Șufi commentaries on the Qur'ān in classical Islam, Routledge studies in the Quran (London; New York: Routledge, 2006), 7. 
kata-kata. Meski demikian pengalaman intuitif ini pada akhirnya juga bersentuhan dengan pengalaman kognitif lainnya, terutama dengan tradisi filsafat. Hal ini kemudian melahirkan istilah semacam sufi nazari/falsafi. Maka tidak heran jika Henry Corbin seorang orientalis yang konsen meneliti filsafat dan mistisisme Islam memasukan sufisme, teosofi (hikmah), ajaran imamah Syi'ah dan ilmu kalam sebagai keluarga filsafat Islam. ${ }^{39}$

Dalam Jawāhir al-Qur'ān al-Ghazali menjelaskan secara rinci mengenai epistemologinya. Ia membagai ilmu al-Qur'an menjadi dua ketegori, yakni ilmu kulit ('ilm al-Ṣadaf) dan ilmu inti ('ilm al-Lubāb). Secara umum istilah ini mirip dengan sisi zahir dan batin al-Qur'an. ${ }^{40}$ Ilmu lapis luar al-Qur'an ada lima. Pertama, ilmu makhārij al-hurūf (fonologi), yaitu ilmu yang berkaitan dengan cara membaca teks. Kedua, ilmu bahasa al-Qur'an, ilmu yang mengkaji kata-kata dari segala aspeknya. Ketiga, ilmu i'rāb al-Qur'ān, dari ilmu ini muncul ilmu keempat yakni ilmu qira'at. Ilmu lapis luar ini kemudian berakhir dengan ilmu yang kelima, ilmu tafsir zahir.41

Sistematika ilmu di atas adalah sistematika membumbung dari partikuar ke universal dan dari bunyi ke makna. Selain itu, ilmu-ilmu di atas juga merupakan sistematika nilai yang bermula dengan yang paling rendah sampai pada yang paling tinggi. Jika ilmu masih mendekati kulit, maka nilainya kecil, sementara nilai ilmu akan bertambah jika menjauh dari kulit awal dan mendekati esensi. Dengan demikian meskipun kelima ilmu diatas berada dalam kategori ilmu kulit, akan tetapi nilainya bertingkat-tingkat.

Ilmu al-lubāb juga memiliki tingkatan-tingkatan sebagaimana ilmu al-Ṣadaf. Tingkatan terendah (al-țabaqah al-suflā) dari ilmu al-lubāb terdiri dari tiga macam ilmu. Pertama ilmu fiqih, al-Ghazali meletakan ilmu fiqih dalam bingkai ilmu dunia, karena dalam pemahaman al-Ghazali ilmu fiqih berfungsi memperkenalkan cara membangun tempat-tempat persinggahan dalam perjalanan, sehingga ilmu ini terkait dengan ilmu-ilmu dunia. ${ }^{42} \mathrm{Al}$-Ghazali menerima ilmu-

${ }^{39}$ Henry Corbin, History of Islamic Philosophy, xv-xvii.

${ }^{40} \mathrm{Abu}$ Hamid Muhammad bin Muhammad al-Ghazāli, Jawāhir al-Qur'ān (Bairut: Dar Ahya' al'Ulum, 1990), 35.

${ }^{41}$ Nasr Hamid Abu Zaid, Mafhūm al-Naș Dirāsah fi 'Ulūm al-Qur'an (Kairo: al-Hay'ah al-Mișriyah al-'Amāh līal-Kitāb, 1990), 281.

42Zaid, Mafhūm al-Naș Dirāsah fi 'Ulūm al-Qur'ān, 297. 
ilmu dunia di antaranya ilmu fiqih selama dalam batas duniawinya. Artinya selama dunia dianggap sebagai penyebarangan darurat menuju akhirat. Dalam konsep ini fiqih berada di tengah-tengah antara ilmu-ilmu dunia dan ilmu-ilmu akhirat. Dari sini dapat dipahami kenapa al-Ghazali terus menyerang ahli fiqih pada masanya. Hal ini dikarenakan mereka telah melampaui batas-batas yang dibutuhkan. Mereka telah memasuki masalah-masalah cabang hanya untuk mencari kedudukan di mata penguasa, sehingga mereka mengubah ilmu dari tujuannya dan menggunakannya untuk mencari kedudukan dan harta duniawi.

Kedua ilmu kalām, al-Ghazali menyebut ilmu kalām dengan istilah "membantah dan mendebat orang-orang kafir". ${ }^{3}$ Ilmu ini dalam perspektif alGhazali berfungsi menjelaskan kesalahan dan membantah dengan argumen yang jelas mengenai kesesatan orang-orang kafir. Ada tiga macam kesesatan orang kafir dalam analisis al-Ghazali, pertama menyebut Allah dengan sebutan yang tidak sepantasnya dengan menyatakan malaikat adalah putri-Nya. Ia mempunyai anak dan sekutu, dan Dia adalah oknum ketiga dalam konsep trinitas. Kedua, menyebut Rasulullah dengan penyair, dukun, pendusta dan mengingkari kenabiannya. Ketiga, mengingkari terhadap hari akhir, kebangkitan, surga, neraka dan pengingkaran terhadap akibat dari ketaatan dan kemungkaran.

Ketiga cerita al-Qur'an (qașaș al-Qur'ān), muncul setelah ilmu kalām dan menjelaskan tentang kondisi orang yang menjalankan suluk dan yang membangkang. Maksud orang yang menjalankan suluk adalah orang yang mendapat keberuntungan di akhirat. Sedang orang yang membangkang adalah orang yang merugi. ${ }^{44}$ Dalam pandangan al-Ghazali fungsi dari kisah dalam al-Qur'an adalah memberikan rasa takut (al-tarhïb), sebagai peringatan (al-tanbīh), dan sebagai pelajaran (al-itibär $)^{45}$ bagi orang-orang sesudahnya.

Selanjutnya mengenai ilmu al-lubāb al-'ulyā (ilmu inti tingkatan atas), ilmu ini mencakup tiga hal, yakni márifatullāh, jalan menuju Allah dan pemberitahuan situasi saat wușūl (pahala dan siksa). Ma'rifatullāh merupakan tujuan yang luhur bagi kehidupan dan ilmu pengetahuan. Sangat wajar jika ayat-ayat yang berhubungan dengan ma'rifatullāh merupakan intisari al-Qur'an. Dari ayat-

43al-Ghazāli, Jawāhir al-Qur'ān, 39.

44Zaid, Mafhūm al-Naș Dirāsah fi 'Ulūm al-Qur'ān, 302.

45al-Ghazāli, Jawāhir al-Qur'ān, 31. 
ayat tersebut muncul ilmu pertama yang masuk dalam kategori ilm al-lubāb al"Ulya. Pada tataran ini fungsi wahyu bukan lagi "penurunan" dari Allah untuk manusia, atau penurunan perintah-perintah dan larangan-larangan-Nya yang bertujuan mewujudkan tatanan manusia yang ideal, tetapi tujuan puncak dari wahyu adalah mengenal Allah. Semakin dekat ilmu tersebut dengan tujuan mengenal Allah, maka nilainya semakin tinggi. ${ }^{46}$

Cara untuk menembus batas-batas kulit agar bisa sampai ke inti adalah dengan konsisten (istiqāmah) di jalan yang lurus dan menjalani suluk menuju Allah. Yakni dengan cara terus menerus berdzikir dan melepas diri dari dunia serta segala sesuatu yang menyibukkannya. Suluk menuju Allah ini memiliki tingkatan-tingkatan dan setiap tingkatan atau maqām membawa pada "suatu keadaan" kema'rifatan. Dengan demikian seseorang yang menjalani suluk berarti melampaui "keadaan" sebelumnya sehingga ia beralih dari ilmu ke ilmu yang lain dalam gerak menaik menuju márifatullāh secara nyata, terbuka dan langsung.

Dengan demikian untuk menembus batas-batas kulit dan memasuki alam inti harus dimulai dari tingkatan yang paling rendah dalam gerak menaik untuk sampai kepuncak márifatullăh. Penyeberangan dari ilmu kulit menuju ilmu inti menurut analisis Nasr Hamid sepadan dengan proses kemunculan khayal dalam hati dari alam indera dan alam nyata menuju alam ghaib dan alam malakut. Jika perpindahan dari alam indera menuju alam malakut melalui wilayah khayal, maka proses penyeberangan dari kulit teks menuju inti teks juga melalui wilayah khayal. Salah satu contoh terbaik untuk menguraikan prosedur yang mempertemukan antara alam indera dan malakut serta menguraikan prosedur ta'will dari kulit teks menuju inti teks adalah mimpi. Alam mimpi merupakan alam yang menjadi penengah antara alam indera dengan alam malakut. Pada alam indera dan alam nyata terdapat bentuk-bentuk dari ide-ide, sedang pada alam malakut terdapat ide maknawi rohani.

Dalam konsep ini bahasa merupakan medium dalam mematerialkan dan menggambarkan yang maknawi. Al-Qur'an sebagai bahasa disini sama dengan alam materiil dan khayal. Ungkapan-ungkapan Al-Qur'an merupakan gambaran

\footnotetext{
${ }^{46}$ al-Ghazali mengistilahkan penjelasan mengenai ma'rifatullah dengan kibrit merah. Pengetahuan ma'rifatullāh ini meliputi pengatahuan tentang Zat Tuhan, sifat-sifat-Nya dan perbuatanperbuatan-Nya. Pengetahuan tentang Zat merupakan pengetahuan yang paling sempit bidangnya, paling sulit digapai dan yang paling susah difikirkan serta paling susah untuk diungkapkan. Oleh karena itu al-Qur'an hanya mengungkapkannya dengan isyarat saja dan ungkapannya suci secara mutlak. Seperti firman Allah dalam surat al-Ikhlas. Lihat, Zaid, Mafhūm al-Naș Dirāsah fi 'Ulūm alQur'än, 284.
} 
dan contoh yang terlihat oleh seseorang dalam mimpinya, sehingga memerlukan ta'bir (tafsir mimpi). Ta'wīl terhadap teks untuk mencapai makna batin yang merupakan inti dari teks sama dengan proses ta'bir mimpi. Istilah ta'wīl dan ta'bir sebenarnya merupakan istilah yang menunjukan satu konsep. Hal ini sebagaimana yang diterangkan oleh al-Ghazali:

"Sesungguhnya, semua yang dimungkinkan untuk dapat kamu pahami diberikan Al-Qur'an dengan cara yang seandainya engkau tidur ruhmu dapat menyaksikan Lawh al-Mahfuz. Niscaya hal itu akan menampakan diri kepadamu dengan contoh yang sesuai yang perlu untuk dita'birkan. Ketahuilah bahwa ta'wïl berfungsi seperti ta'bir."47

Setiap kata-kata dalam al-Qur'an menjadi gambar-gambar seperti yang dilihat oleh orang yang tengah bermimpi. Gambar-gambar yang diperoleh dari kata-kata al-Qur'an merupakan gambar meteriil yang perlu diungkap makna yang tersimpan di dalamnya. Dengan demikian bahasa berubah dari tataran semantik menjadi simbol-simbol bagi hakikat-hakikat yang tersembunyi di dalam alam ide dan alam roh.

Al-Ghazali memberikan contoh-contoh dari konsep di atas dengan:

"Perhatikan sabda Nabi: hati orang yang beriman berada diantara dua jari sang Pengasih, sebab inti makna jari adalah kemampuan untuk membalik dengan cepat. Hati orang yang beriman berada di antara genggaman setan dan genggaman malaikat. Yang satu menyesatkan dan yang satunya memberikan petunjuk. Allah melalui keduanya membolak-balikkan hati hamba-hamba-Nya seperti engkau membolak-balikan sesuatu dengan kedua jarimu.

Perhatikan bagaimana dua malaikat yang tunduk kepada Allah menyatukan jari-jemarimu dalam jari-jemarinya yang mempunyai kesamaan inti makna, namun berbeda bentuknya. Jika kamu mengetahui makna jari maka kamu dapat memahami pena,tangan, kanan, wajah dan bentuk. Semua mengambil makna rohani bukan makna jasmani."48

Dalam tulisanya al-Ghazali mengungkapkan dikotomi bentuk dan makna dengan dikotomi-dikotomi lain seperti, bayangan dan roh, inderawi dan maknawi, simbol dan yang disimbolkan, yang nyata dan yang ghaib dan lain sebagainya. Akan tetapi, dikotomi yang mendasar yang dapat diterima oleh

47al-Ghazāli, Jawāhir al-Qur'ān, 52.

48al-Ghazāli, Jawāhir al-Qur'ān, 49-50. 
semua struktur pemikiran adalah dikotomi dunia dan akhirat. Dunia merupakan alam gambar, bayangan, ide, indera dan simbol sedang akhirat merupakan alam ide, roh, yang disimbolkan yaitu alam ghaib. Segala sesuatu yang ada di dunia ini akan lenyap dan $f a n \bar{a}^{\prime}$ dan segala sesuatu yang berkaitan dengan dunia tidak memiliki nilai dan signifikasi. Dalam tataran ini yang penting bukanlah gambar akan tetapi maknalah yang penting. Sebuah simbol memiliki nilai karena ia menunjuk pada yang disimbolkan.

Hubungan antara makna dan bentuk merupakan hubungan subtansional dimana yang muncul di alam dunia adalah bentuk sementara yang mucul di

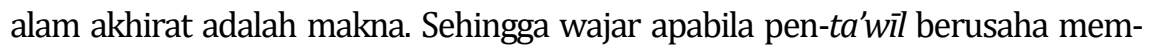
bedah untuk dapat menembus dari kulit ke menuju inti atau dari simbol menuju hal yang disimbolkan. Perjalanan dari kulit teks menuju inti teks atau makna teks ini tidak kalah sulitnya dengan mi'raj para sufi dalam berusaha merangkul hakikat. Hanya saja, para sufi merangkulnya dalam konteks márifat sedang para pen-ta'will melalukannya hal itu melalui teks. Bila alam ini hanyalah khayalan dan hakikat terletak di sana, maka untuk sampai ke hakikat adalah melalaui teks atau mi'raj ma'rifat yang merupakan wusul menuju makna yang hakiki bagi yang ada atau teks. Makna yang rohani merupakan makna yang hakiki sedang makna materiil merupakan makna majazi yang menunjukan kepada makna hakiki dari sisi yang samar.

Dengan demikian, epistemologi sufi al-Ghazali merupakan mobilisasi semantik dari alam duniawi yang merupakan alam indera dan alam nyata ke arah alam malakut atau alam ghaib..$^{49}$ penyeberangan dari alam indera ke alam malakut atau dari 'ilm al-Ṣadaf ke 'ilm al-Lubāb hanya dapat dilakukan oleh orang-orang yang suluk kepada Allah. Menurut al-Ghazali dalam memahami alQur'an mayoritas umat Islam berhenti pada tafsir z̧āhir yang notabenya merupakan 'ilm al-Sadaf dan hanya sebagian orang saja yang mampu menembus ke dalam 'ilm al-Lubāb.

Ditinjau dari perspektif epistemologi ala Abid al-Jabiri, epistemologi sufi ini masuk dalam kategori epistemologi 'irfānī. Istilah irfān berasal dari bahasa Arab 'arafa yang memiliki makna sama dengan ma'rifah, yang berarti pengetahuan, namun berbeda dengan ilmu ('ilm).50 Pengetahuan irfānī diperoleh secara

${ }^{49}$ Nasr Hamid Abu Zaid, Teks Otoritas Kebenaran (Yogyakarta, LKiS, 2012), 241.

50al-Jābirī, Bunyah al-'Aql al-'Araby, 251. 
langsung dari Tuhan (kashf) lewat olah rohani (riyādah) yang dilakukan atas dasar hubb (cinta) atau irādah (kemauan kuat), sedang ilmu menunjuk pada pengetahuan yang diperoleh melalui transformasi (naql) atau rasionalitas ('aql.51 Dalam khazanah filsafat Barat pengetahun 'irfānī ini disebut dengan istilah knowledge of (pengetahuan tentang) yaitu pengetahuan intuitif yang diperoleh secara langsung. Berbeda dengan knowledge about (pengetahuan mengenai) yang merupakan pengetahuan diskursif yang diperoleh melalui perantara indra atau rasio. 52

Epistemologi 'irfānī ini berkembang dan digunakan masyarakat sufi, berbeda dengan bayānī yang dikembangkan dan digunakan dalam keilmuankeilmuan Islam pada umumnya. Epistemologi ini kadang dianggap sebagai "lawan" dari epistemologi bayānī. Diadilinya al-Hallaj di tiang gantungan menjadi bukti bahwa epistemologi bayānī menjadi epistemologi yang populer dan memiliki pengaruh di wilayah kekuasan Islam.

Pengalaman-pengalaman bațin yang amat mendalam, otentik, fitri, hạanafiyyah samhah dan hampir-hampir tak terkatakan oleh logika dan bahasa inilah yang disebut dengan istilah al-ilm al-hudury (direct experince) oleh tradisi ishraqi di Timur atau preverbal, prereflective consciousness atau prelogical knowledge oleh tradisi eksistensial Barat. Validitas kebenaran epistemologi irfān hanya dapat dirasakan dan dihayati secara langsung (direct experience), intuisi atau psiko-gnosis. ${ }^{53}$

Ada tiga cara untuk mengungkapkan makna atau dimensi batin yang diperoleh dari kashf, yakni: Pertama, diungkapkan dengan cara i'tibar atau qiyās 'irfāni. Yaitu dengan cara analogi makna batin yang ditangkap dalam kashf kepada makna zahir yang ada dalam teks. Kedua diungkapkan dengan shațahat suatu ungkapan lisan tentang perasaan (al-wijdan) karena limpahan pengetahuan langsung dari sumbernya. Ketiga, dengan menggunakan simbol-simbol. Menurut al-Ghazālī pengungkapan pengetahuan 'irfānī dengan simbol-simbol ini dilakukan berdasarkan adanya kesulitan menjelaskan pengalaman spiritual

${ }^{51}$ Khudari Soleh, Filsafat Islam dari Klasik Hingga Kontemporer (Yogyakarta: ar-Ruzz Media, 2013), 253.

52Loius O. Kattsoff, Pengantar Filsafat (Yogyakarta: Tiara Wacana, 2004), 141.

${ }^{53}$ Amin Abdullah, Islamic Studies di Perguruan Tinggi; Pendekatan Integratif-Interkonektif (Yogyakarta: Pustaka Pelajar, 2006), 208-9. 
kepada orang lain yang belum tentu ada padanannya dalam dunia empirik. Menurutnya, pengelaman spiritual sufisme sangat dalam dan rumit sehingga kata-kata yang berusaha menjelaskannya pasti akan salah dan tidak tepat.

Dalam istilah lain al-Ghazali menyebutnya dengan ilmu mukashafah. Merupakan kebenaran abstrak yang berada di alam ide, nyata dan transendent. Jenis ilmu ini, sulit diungkapkan dengan kata-kata dalam pembicaraan. Hal ini disebabkan mukashafah merupakan kebenaran yang bersifat vertikal yang bermuara langsung kepada Allah. Sementara al-Qur'an dan hadis merupakan book guide untuk mencapai pengetahuan ini. ${ }^{54}$

Jika epistemologi bayānī merupakan nalar yang tumbuh dari dalam rahim kebudayaan Arab, dan jika epistemologi 'irfānī pada awalnya merupakan manifestasi dari perlawanan politik terhadap otoritas sekelompok kaum, maka tidak dengan epistemologi burhānī. Kehadiran epistemologi burhānī di tengah masyarakat Arab-Islam dapat dikategorikan sebagai upaya dalam menyelaraskan antara epistemologi burhānī itu sendiri dengan epistemologi bayānī. Tidak seperti epistemologi 'irfānī yang kontradiktif dengan epistemologi bayānī. Hal ini mengingat para pemikir burhānī menyadari penuh bahwa epistemologi bayānī merupakan satu-satunya nalar yang "genuine" dari rahim kebudayaan ArabIslam. .5

Dalam perkembanganya ketiga epistemologi di atas saling berbenturan satu sama lain. Benturan-benturan epistema tersebut merupakan perdebatan antagonistik fuqaha' vis a vis kaum sufi (bayānī vs. 'irfānī), fuqaha' vis a vis filosof (bayānī vs. burhānī), filosof vis a vis kaum sufi (burhānī vs. 'irfānī). ${ }^{56}$ Benturanbenturan itu dianggap sebagai ekspresi basis epistemologi pada abad ke-5 Hijriah. Untuk meredam dan menjembatani krisis basis epistemologi ini, kaum sufi sunni dan kaum filosof berupanya melakukan harmonisi elektik. Suhrāwardi mencoba mensintesikan antara tradisi burhānī dan 'irfānī dengan hikmah al-

\footnotetext{
${ }^{54}$ Agus Sutiyono, "Ilmu Ladunni dalam Perspektif al-Ghazali," Nadwa 7, No. 2 (22 Maret 2016): 316, https://doi.org/10.21580/nw.2013.7.2.564.

55M. Faisol, “Struktur Nalar Arab-Islam Menurut Abid al-Jabiri,” Tsaqafah 6, No. 2 (2010): 356.

${ }^{56}$ Status dan keabsahan 'irfānī selalu dipertanyakan baik oleh tradisi berfikir bayānī atau burhānī. Epistemologi bayānī mempertanyakan keabsahannya karena dianggap terlalu liberal karena tidak mengikuti pedoman-pedoman yang diberikan teks, sedang epistemologi burhānī mempertanyakan keabsahannya karena dianggap tidak mengikuti aturan-aturan dan analisis yang berdasarkan logika. Lihat Abdullah, Islamic Studies di Perguruan Tinggi, 206-7.
} 
ishrāqiyyah-nya yang kemudian dikenal dengan madhhab tasawuf falsafi-nya. Muhāsibi juga mencoba mengharmonisasikan secara elektif antara nalar bayānī dan 'irfānī yang kemudian dikenal dengan mazhab tasawuf Sunni.

Upaya penggabungan dua epistemologi ini disadarkan atas kritik Suhrāwardi terhadap kekurangan dan kelemahan burhānī. Menurutnya rasionalisme burhānī mengandung beberapa kelamahan antara lain, bahwa ada kebenaran-kebenaran yang tidak bisa dijelaskan dengan atau didekati dengan rasio, misalnya hal-hal yang berkaitan dengan substansi atau konsep mental. ada eksisntensi di luar pikiran yang bisa dicapai dengan nalar namun tidak bisa dijelaskan secara logika, seperti soal warna, bau, rasa atau bayangan. ${ }^{57}$

Sebagaimana Suhrāwardi dan Muhasibi yang melakukan dialektika antara dua epistema, al-Ghazali juga melakukan upaya penyelarasan antara epistemologi bayānī dan 'irfānī. Bagi al-Ghazali kedudukan sentral teks (naql) sebagai sumber pengetahuan adalah hakikat bayānī. Oleh karena itu al-Ghazali mengatakan bahwa yang dimaksud dengan bayānī sebenarnya adalah dalil sami' (wahyu) yang merupakan dalil yang paling kuat. Hal ini dikarenakan kemunculan dali sami' tidak dengan cara yang wajar, melainkan dengan cara mu'jizat. Untuk memperkuat pendapatnya, al-Ghazali mengutip pendapat Qāḍi 'Abd al-Jabbār, bahwa bayan adalah dalil yang sesungguhnya. Hal ini terungkap misalnya melalui kalimat bayyana Allāh al-āyāta li 'ibādih (Allah telah menjelaskan/memberi dalil tanda-tanda bagi para hamba-Nya). Jadi sebenarnya alGhazali menyakini dan konsisten bahwa teks adalah sumber pengetahuan. ${ }^{58}$

Namun di sisi lain al-Ghazali juga menyatakan bahwa teks memiliki sisi zahir dan sisi bațin. Dikotomis lahir-batin merupakan isu sentral dari epistemologi 'irfānī. Sebagaimana yang telah dijelaskan sebelumnya, dikotomis ini bukan merupakan hal yang kontradiktif namun merupakan pasangan. Aspek zahir teks adalah tilawah sedangkan aspek bațin adalah ta'wil-nya. ${ }^{59}$ Menurut Nicholson (1868-1945 M) dan T.J. Dr Boer (1866-1942), di tangan al-Ghazali epistemologi 'irfān menjadi jalan yang jelas karakternya untuk mencapai ma'rifat dalam tauhid dan kebahagiaan.

\footnotetext{
${ }^{57}$ Waryani Fajar Riyanto, "Antisinonimitas Tafsir Sufi Kontemporer," Epistemé: Jurnal Pengembangan Ilmu Keislaman 9, no. 1 (2014): 145.

${ }^{58}$ Sibawaihi, Eskatologi al-Ghazālī dan Fazlur Rahman; Studi Komparatif Epistemologi KlasikKontemporer (Yogyakarta: Penerbit Islamika, 2004), 167.

${ }^{59}$ Soleh, Filsafat Islam dari Klasik hingga Kontemporer, 270.
} 
Dualisme teks keagamaan ini (zahir dan batin) ditinjau dari perspektif filasafat mirip dengan pemikiran filsafat Plato ${ }^{60}$ yang mengajukan gagasan dualisme, yaitu dunia idea (nyata) dan dunia non-idea (tidak nyata). ${ }^{61}$ Idea adalah tujuan akhir dari segala wujud inderawi. Meskipun al-Ghazāī secara ekplisit tidak menjelaskan akar pemikirannya tersebut berasal dari Plato, namun al-Ghazālì menyebutkan bahwa yang paling banyak mempengaruhi pemikiran filosofisnya adalah Ibn Sina dan al-Farabi.62 Sedang al-Farabi merupakan filosof Muslim yang terpengaruh oleh gagasan dualisme Plato dan diklaim sebagai pendiri neo-platonisme Arab.63 Gagasan dualisme ini dalam perspektif al-Farabi disebut dengan istilah al-mawjūdāt al-rūhiyyah (wujud spiritual) dan al-mawjūdāt al-mādiyah (wujud-wujud material). ${ }^{64}$

Kolaborasi antara epistemologi bayānī dan 'irfānī yang diupayakan oleh alGhazali terlihat jelas dalam karya monumentalnya 'Ihya' 'Ulūm al-Dīn. Secara redaksional, susunan dari kitab ini mengikuti susunan kitab fiqh pada umumnya, namun kemudian dalam pembahasannya selain membahas masalah fiqh yang merupakan salah satu cabang pengetahuan yang menggunakan epistemologi bayānī, al-Ghazali juga membahas masalah tasawuf yang menggunakan epistemologi 'irfānī. 65

\footnotetext{
${ }^{60}$ Tamara Albertini, "Crisis and Certainty of Knowledge in al-Ghazāī (1058-1111) and Descartes (1596-1650)," Philosophy East and West 55, No. 1 (2005): 4.

${ }^{61}$ Nasirudin Khasru berpendapat bahwa kalau diteliti asal usul dari lahirnya kemungkinan penafsiran melalui simbol dan isyarat (dualisme zahir-bațin) pada akhirnya akan bersinggungan dengan lembaran-lembaran ketuhanan Plato dan aliran idealismenya. Hal ini karena alam semesta yang terpampang dengan fenomena-fenomena tertentu, apabila wujud nyatanya merupakan kepanjangan dari akal universal, maka intisari perumpaan tersebut juga dapat diterapkan pada lafal yang tersurat sebagai alam semesta yang tampak. Kemudian aspek lafziah ini menjadi multi interpretatif, sementara hakikat terletak di alam idea yang lafal-lafalnya dianggap sebagai korpus yang mewadai. Lihat, Goldziher, Madhāhib al-Tafsìr al-Islāmī, 204.

${ }^{62} \mathrm{Abu}$ Hamd Muhammad bin Muhammad al-Ghazāli, Tahāfut al-Falāsifah (Kairo: Dār alMa'ārif, 1966), 20. Meski kemudian al-Ghazālī mengklaim bahwa pemikiran kedua filsuf Islam ini dibagi menjadi tiga bagian yakni, yang wajib dikafirkan, wajid dibid'ahkan dan bagian yang tidak wajib diingkari sama sekali. Lihat, Abu Hamd Muhammad bin Muhammad al-Ghazālī, al-Munqiz min I-Dalāl (Beirut: Maktabah al-Sa'biyyah, t.th.), 45-46.

63Sibawaihi, Eskatologi al-Ghazālī dan Fazlur Rahman, 215.

${ }^{64}$ Soleh, Filsafat Islam dari Klasik hingga Kontemporer, 144.

${ }^{65}$ Menurut Amin Abdullah kelemahan yang paling mencolok dalam tradisi berfikir epistemologi bayānī adalah ketika ia harus berhadapan dengan teks-teks keagamaan yang dimiliki komunitas, kultur,bangsa atau masyarakat yang beragama lain. Ketika berhadapan dengan komunitas agama lain, corak argumen berpikir keagamaan model bayānī biasanya mengambil sikap mental yang dogmatik, defensif, apologis dan polemis dengan semboyan kurang lebih semakna dengan "right or wrong my country".
} 
Contoh dapat dilihat dalam kitab Ihyā' Ulüm al-Dīn ketika menjelaskan tentang keutamaan sujud:

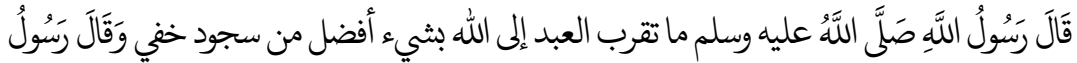

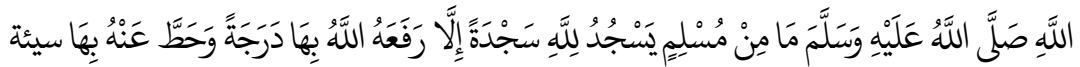

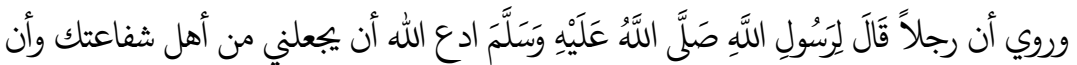

$$
\begin{aligned}
& \text { يرزقني مرافقتك في الجنة فقال صلى الله عليه وسلم أعني بكثرة السجود وقيل إن أقرب ما يكون } \\
& \text { العبد من الله تعالى أن يكون ساجداً وهو معنى قوله عز وجل واسجد واقترب وقال عز وجل } \\
& \text { سيماهم في وجوههم من أثثر السجود فقيل هو ما يلتصق بوجوههم من الأرض عند السجود وقيل هو }
\end{aligned}
$$

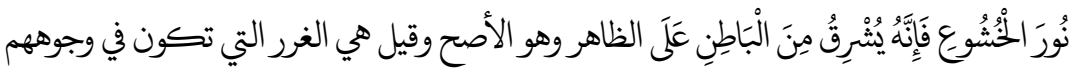

$$
\begin{aligned}
& \text { يوم القيامة من أثر الوضوء وقال صلى الله عليه وسلم إذا قرأ ابن آدم السجدة فسجد اعتزل الشيطان } \\
& \text { يبكي ويقول يا ويلاه أمر هذا بالسجود فسجد فله الجنة وأمرت أنا بالسجود فعصيت فلي النارويروى } \\
& \text { عن علي بن عبد الله بن عباس أنه كان يسجد في كل يوم ألف سجدة وكانوا يسمونه السجاد.66 }
\end{aligned}
$$

Dalam kutipan di atas nampak bagaimana al-Ghazali memaparkan hadishadis Nabi terlebih dahulu sebelum membahas dimensi batin dari keutamaan sujud. Dalam perspektif al-Jabiri model penjelasan seperti ini merupakan ciri khas dari epistemologi bayānī. Sementara dimensi irfānī nampak dari penjelasan al-Ghazali perihal athar sujud. Al-Ghazali mendefinisikan athar sujud dengan:

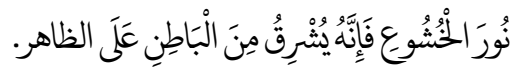

Dalam perspektif al-Ghazali athar sujud muncul dari dalam/batin dan bersumber dari cahaya kekhusukan seorang hamba dalam beribadah. Cara menjelaskan yang menekankan aspek batin merupakan ciri khas dari epistemologi irfānī. Sehingga dari contoh di atas nampak jelas bagaimana al-Ghazali melandasi pembahasan dengan epistemologi bayānī kemudian pembahasannya bergeser ke epistemologi 'irfānī.

66al-Ghazāli, 'Thyā' 'Ulūm al-Dīn, 176-77. 


\section{E. Kesimpulan}

Dalam sejarah perkembangannya keabsahan hasil penafsiran yang dilakukan oleh kaum sufi masih diperdebatkan. Sebagian ulama menerima dan sebagian lain tidak mengakuinya sebagai tafsir. Meskipun demikian, tafsir yang dilakukan oleh kaum sufi menjadi corak tersendiri yang khas dengan epistemologi 'irfānī yang dominan. Sisi zahir dan batin merupakan landasan utama epistemologi yang dikembangkan oleh kaum sufi. Model ini juga dikembangkan oleh al-Ghazali namun dengan nomenklatur yang berbeda, ia menyebutnya dengan istilah 'ilm șadf untuk sisi zahir dan 'ilm lubāb untuk sisi batin.

Meskipun al-Ghazali mengembangkan epistemologi 'irfānī dalam memahami al-Qur'an, namun dalam faktanya ia juga melakukan harmonisasi antara irfānī dan bayānī. Harmonisasi ini tetap menjadikan epistemologi irfānī sebagai landasan utama. Proses dialektika yang dilakukan oleh al-Ghazali ini merupakan implikasi dari upaya menselaraskan antara zahir ayat yang cenderung bayānī dengan batin al-Qur'an yang dekat dengan epistemologi irfānī. Bagi al-Ghazali merupakan hal yang tidak tepat apabila mengaku telah paham batin al-Qur'an tanpa melalui sisi zahir al-Qur'an. Memahmi zahir ayat merupakan syarat untuk memperoleh pemahaman dari sisi batin al-Qur'an.]

\section{DAFTAR PUSTAKA}

Abdullah, Amin. Islamic Studies di Perguruan Tinggi; Pendekatan IntegratifInterkonektif. Yogyakarta: Pustaka Pelajar, 2006.

Alusī, Maḥmud al-. Rüḥ al-Ma'âni. Vol. I. Beirut: Dar Ihya' al-Turath al-'Araby, t.th.

Azra, Azyumardi. "Al-Ghazālī." Ensiklopedi Islam. Jakarta: Ichtiar Baru Van Hoeve, 2005.

Badawi, Rahman. Muallafāt al-Ghazāli. Kuwait: Wakālah al-Mațbū'āt, 1977.

Chasbullah, Arif Chasbullah, dan Wahyudi Wahyudi. "Deradikalisasi Terhadap Penafsiran Ayat-ayat Qital." Fikri: Jurnal Kajian Agama, Sosial dan Budaya 2, no. 2 (Desember 2017): 407-424.

Corbin, Henry. History of Islamic Philosophy. London: The Institute of Ismaili Studies, t.th. 
al-Dhahāby, Husayn. al-Tafsīr wa al-Munfasirūn. Vol. II. t.tp: Maktabah Muș'ab bin 'Amr al-Islamiyah, 2004.

Faisol, M. “Struktur Nalar Arab-Islam Menurut Abid al-Jabiri." Tsaqafah 6, no. 2 (2010): 335-359.

Gandhi, Mohandas. "Karamchand (1869-1948)." Global Encyclopaedia of Islamic Mystics and Mysticism 1 (2009): 407.

Ghazāli, Abu Hamid Muhammad bin Muhammad al-. 'Ihyā' 'Ulūm al-Dīn. Beirut: Dār Ibn Hazm, 2005.

—__Jawāhir al-Qur'ān. Bairut: Dar Ahya' al-'Ulum, 1990.

——_. Mishkāt al-Anwār. Bairut: 'Ālam al-Kutub, 1982.

—_- Taḥāfut al-Falāsifah. Kairo: Dār al-Ma’ārif, 1966.

Ghazanfar, Shaikh M, Abdul Azim Islahi, Economic thought of al-Ghazali (450505 A.H./1058-1111 A.D.). Jeddah, Saudi Arabia: Scientific Pub. Center, King Abdulaziz University, 2011.

Goldziher, Ignaz. Madhāhib al-Tafsīr al-Islāmī. Kairo: Maktabah al-Khānja, 1955.

al-Istambūly, Ismāil Haqqy. Rūḥ al-Bayān. Vol. I. Beirut: Dar Ihya' al-Turath al'Araby, t.th.

Jābirī, Muhammad 'Abid al-. Bunyah al-'Aql al-'Arabī. Beirut: Markaz Dirāsāt al-Wahdah al-'Arabiyyah, 2009.

Kattsoff, Loius O. Pengantar Filsafat. Yogyakarta: Tiara Wacana, 2004.

Kurdi, dkk. Hermeneutika al-Qur'an dan Hadis. Yogyakarta: el-Saq, 2010.

Maryam, Musharraf. "A Study on the Sufi Interpretation of Qur'ān and The Theory of Hermeneutic." Al-Bayan Journal 11, no. 1 (2013): 33-47. https://doi.org/10.11136/jqh.1311.01.03.

Massignon, Muhammad 'Abd al-Rāzaq Louis. al-Tașawwuf. Beirut: Dār alKitab al-Lubnani, 1984.

Ms, Fayzullayeva. "Ethics of Communication in Philosophy Muhammad AlGhazali." Arts and Social Sciences Journal 09, no. 03 (2018). https://doi.org/10.4172/2151-6200.1000345.

Mujib, Abdu. Biografi al-Ghazali Beserta Karya-karyanya. t.tp: CV Bintang Remaja, t.th.

Riyanto, Waryani Fajar. "Antisinonimitas Tafsir Sufi Kontemporer." Epistemé: Jurnal Pengembangan Ilmu Keislaman 9, no. 1 (2014): 139-154. 
Salleh, Kamarudin Haji. "An Examination on the Nature of al-Ghazali Sufism." Islāmiyyāt 17 (1996).

Sands, Kristin Zahra. Șüfi commentaries on the Qur'ān in classical Islam. Routledge studies in the Quran. London: New York: Routledge, 2006.

Schimmel, Annemarie. Mystical Dimensions of Islam. Chapel Hill: The University of North Carolina Press, 1975.

Shihab, M. Quraish. Kaidah Tafsir. Tangerang: Lentara Hati, 2013.

Sibawaihi. Eskatologi al-Ghazālī dan Fazlur Rahman; Studi Komparatif Epistemologi Klasik-Kontemporer. Yogyakarta: Penerbit Islamika, 2004.

Soleh, Khudari. Filsafat Islam dari Klasik Hingga Kontemporer. Yogyakarta: arRuzz Media, 2013.

Sulamī, Abū Abd al-Raḥman al-. Haqāiiq al-Tafsīr. Vol. I. Beirut: Dār al-kutub al-'Ilmiyah, 2001.

Sutiyono, Agus. "Ilmu Ladunni dalam Perspektif al-Ghazali." Nadwa 7, no. 2 (22 Maret 2016): 310. https://doi.org/10.21580/nw.2013.7.2.564.

Taftazāni, Abu Wafa al-. al-Madkhal ilā al-Tașawwuf al-Islāmy. Kairo: Dār alThaqāfah li al-Nashr wa al-Tawzi', t.th.

Tamara Albertini. "Crisis and Certainty of Knowledge in Al-Ghazāli (10581111) and Descartes (1596-1650)." Philosophy East and West 55, no. 1 (2005): 1-14.

Țabāțabāi, al. al-Mizān. Vol. V. Beirut: Ismailiyan, Dar al-Kutub al-Islamiya, t.th.

Tustari, Saḥl al-. Tafsir al-Qur'an al-Azīm. Kairo: Dār al-Hir lī al-Turath, t.th.

Wahyudi. “Ta'wīl Sufi al-Ghazali dan ibn 'Arabī terhadap Ayat-ayat al-Qur'an (Studi Komparatif)." Master's Thesis, UIN Sunan Ampel Surabaya, 2017.

Zaid, Nasr Hamid Abu. Mafhūm al-Naș Dirāsah fi 'Ulūm al-Qur'ān. Kairo: alHay'ah al-Mișriyah al-'Amāh lī al-Kitāb, 1990.

Zarkashi, Badr al-Dīn al-. Al-Burhān fì 'Ulūm al-Qur'ān. Vol. II. Beirut: Dār alKutūb al-'Ilmiyah, 2012.

Zarqāny, Abd al-'Ażim al-. Manāhil al-Irfān fì 'Ulūm al-Qur'ān. Vol. II. Beirut: Dār al-Fikr, 1988. 
